\section{Lucretius or Kapteyn?}

NONNE vides etiam diversis nubila ventis diversas ire in partis inferna supernis? Qui minus illa queant per magnos ætheris orbis æstibus inter se diversis sidera ferri? De Rerum Naturâ, v., 646́-9.

See you not too that clouds from contrary winds pass in contrary directions, the upper in a way contrary to the lower? Why may not yon stars just as well be borne on through their great orbits in ether by currents contrary one to the other?

\section{Munro's Translation.}

E. J. M.

\section{Semi-absolute.}

THE biologist, even the most mathematical, envies and admires the greater precision of statement and
THE MAKING OF MOLNTAINS.`

THE object of the very attractive volume before us, as stated by its author, is to supply geographers with such a knowledge of geological processes as is necessary for understanding the origin of the orographic features of the earth's surface. With this purpose in view, technical details are-so far as is possible-avoided, while disputed and doubtful topics are, as a rule, kept in the background; while by vivid and picturesque descriptions, aided by admirable photographic illustrations and diagrams, the reader is madeacquainted with the chief types of mountain forms. and the agencies by which they have been produced.

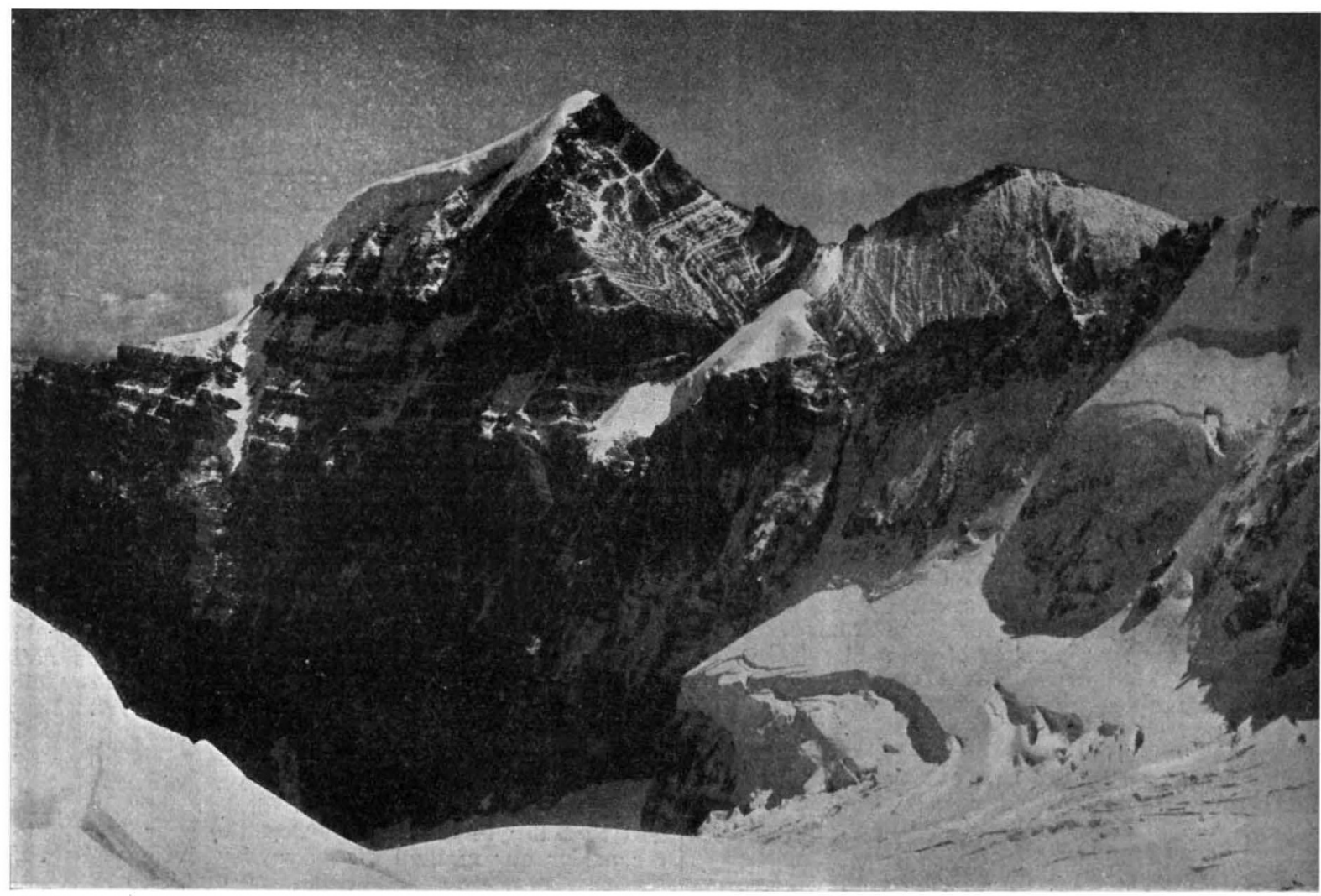

Photo.]

[Wehrli, Zürich.

FIG. r.-The Bifertenstock and Frisal, seen from the Firn plateau of the Tödi. Eocene and Mc sozoic strata resting upon Gneiss. From "Mountains: their Origin, Growth, and Decay."

language that is possible for the physicist, and the physicist in his turn is apt to plume himself on the fact that his sciences, as compared with those of the bjologist, are the exact sciences. Some biologists interested in precision of terminology have been wondering what the physicist may mean br the term "semiabsolute"-a term which will be found applied to volts in the title of a paper recently read before the Royal Society (Nature, December 25, r913, p. 495 , column I). On the face of it, semi-absoluteness is no more easy to conceive than is semi-infinity, and one is therefore tempted to regard the phrase alkin to the "quite all right" of the modern young lady, the "quite a few" of the American, and other such degeneracies of modern speech. That view must, of course, be wrong, but an explanation would be comforting to more than one

ENQUTRER
The great majority of the elevations of the land are classed as "original or tectonic," the building-up of these structures being due to many diverse agencies; only a small residue of the relief-forms are grouped as "subsequent or relict" mountains, being the result of operations that, by removing the surrounding materials, have left great upstanding masses behind.

First among the tectonic mountains are included those of volcanic origin, grouped by the author as "débris cones," which are made up of fragmental materials, usually of igneous origin but often accompanied by detritus from aqueous 15 Mountains: their Origin, Growth, and Decay." By Frof. James Geikie, F.R.S. Pp. xix $+31 \mathrm{I}+1 \mathrm{x} x \mathrm{x}$ plates. (Edinburgh: Oliver and Boyd,

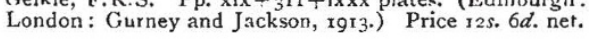

$$
\text { NO. } 2306 \text {, VOL. 92] }
$$

